\title{
How Scotch Whisky is Fueling Decades of Good Works
}

\author{
Niall MacKenzie (University of Glasgow) \\ Martin Gannon (University of Edinburgh) \\ Jillian Gordon (University of Glasgow)
}

KEYWORDS: Entrepreneurship, Philanthropy.

What do successful entrepreneurs do beyond generating wealth? This question holds interest for so many of us. Many wealthy individuals have the ability to buy whatever they want, do whatever they please, live wherever they want. Yet sometimes they also yearn to make sense of their wealth by helping others. When individuals reach a certain level of achievement, we see many entrepreneurs switch their attention to philanthropy. But why is this, and what motivates entrepreneurs to give away their wealth?

This question is worth considering, both for founders of successful companies who want to have impact well beyond their tenure in business and for family businesses whose stewardship under future generations is uncertain.

Our research paper, entitled "A Spirit of Generosity: Philanthropy in the Scotch Whisky Industry" (https://www.cambridge.org/core/journals/business-hist ory-review/article/spirit-of-generosity-philanthropy-in-the -scotch-whisky-

industry/1C3A1B9A8F2AF3903D8C791DCF64790B)

and published in Harvard's Business History Review, provides some clues. Through analyzing the story of three sisters, their family business and journey into philanthropy, we discovered how entrepreneurs can engage in philanthropy for both altruistic and practical reasons. Our case study of the Scotch whisky company Edrington and its origins revealed a fascinating story of the Robertson sisters, who 60 years ago created an evergreen philanthropic-commercial hybrid company that continues to fund worthy causes today, while protecting the company and its employees from takeovers. If you enjoy a certain type of Scotch on occasion (or more often), it may surprise you to know that your enjoyment is also contributing to charity.

\section{Fending off taxes and takeovers}

In 1961, three Scottish sisters Elspeth, Agnes, and
Ethel Robertson faced a difficult situation after inheriting the family Scotch business. The business was very successful, and they'd lived a life of privilege. The sisters were all single, childless, and getting on in age. They feared estate taxes would cripple the business and leave it exposed to takeovers and being broken up, leaving their staff exposed and their own involvement in the business side-lined. Having already seen off takeover attempts from international distillers, which the sisters rejected in favor of ensuring the business remained domestically owned. They were determined that the business should remain in Scotland, making Scotch.

As we know, successful entrepreneurs will often face choices about whether or not to sell their businesses at certain points in time, typically when they've reached a certain level of success. They may be offered a great deal of money for their business, or they may wish to pass it on to their family or attempt to create some kind of legacy. But what happens when you don't have any family to pass it on to? Should you sell? Close it down? Give it away?

The sisters decided to give away all of their shares in the family business to charity. They were deeply concerned about estate taxes, a potential takeover, and the effect on their employees. By giving it away they were able to retain control. To do so they created a new business entity by merging their Scotch whisky interests into a new company, Edrington. They then created their own charity, named the Robertson Trust, to which they gave all of their shares in the new business.

In one fell swoop the sisters ensured that they and their family business would remain in the Scotch whisky industry forever, protecting it against takeover, while simultaneously ensuring that the substantial wealth they inherited would be put to good causes in perpetuity via these two organizations. The sisters ran both the charity and the business until their deaths, with the support of 
professional management who then took over.

\section{A charitable powerhouse}

The sisters shunned publicity to the extent that very few people knew who they were or what they did outside of the industry. Their donations were almost always anonymously given or given on the condition of strictly no publicity. As a result, there was almost no return to their reputation whilst alive, any elevation in their position in society, or any reputational benefit to the company.

What the sisters' foresight did do is ensure that their ambitions for the company and the charity would continue to be realised 60 years after they funded both, and over 30 years since the last of them died. To date the charity has given away over $£ 300 m$ (or over $\$ 400$ million in US dollars) in charitable donations and support around Scotland, whilst the company now turns over around $£ 700 \mathrm{~m}$ per year (or nearly $\$ 1$ billion in US dollars), is a global multinational, and one of the major Scotch whisky producers in the world.

The Macallan, Highland Park, The Glenrothes, and Famous Grouse Scotch whiskies are renowned the world over and are part of Edrington's brand portfolio. When you order one of these Scotches you are effectively supporting charity as a result of the three sisters' foresight and philanthropic vision. Its products are renowned for their quality, and The Macallan is regularly cited as the most prestigious and collectable Scotch whisky in the world.

\section{Cementing a legacy}

The sisters' story tells us a great deal about the noneconomic motivations of entrepreneurs and how to build a legacy. From inheriting a successful family business through to growing it then giving it away, the sisters showed it is possible to be both commercially successful and societally-minded. Their focus on the wellbeing of their staff and desire to channel their wealth towards societal benefit was matched by their wish to retain the independence of their business in an industry dominated by takeovers. This meant they had to be bold in their actions to secure a legacy of giving that characterized their lives.

Through their decision to give away their ownership in the company to charity, the sisters created a dualpurpose vehicle that sees the company remit dividend payments back to the charity which are then used to support good causes. The Robertson Trust is now one of Scotland's largest charities as a direct result of this structure, and the sisters' foresight.

Whilst the sisters sought no publicity during their lifetimes, their story has become increasingly known around the world as time goes on. They never sought fame (or even fortune), but their innovative solution to their situation and the challenges they faced meant they've now established a way to keep their name and desire to do good in Scotland alive perhaps forever. As far as what comes after success for entrepreneurs, for the sisters it seems the answer lies in the bottom of a glass of good Scotch...

\section{Takeaways}

Successful entrepreneurs who want to create a legacy of good works themselves can learn from the experience of the Robertson sisters. Here are some things to consider:

- There is a lot of buzz nowadays surrounding "BCorps", which enable companies to focus on social aims in addition to financial goals. This historical case shows that even established companies can do a "re-set" of their mission. Sometimes to retain control of your business you need to give it away - smartly.

- The sisters knew they couldn't avoid estate taxes, which would open the door to takeover, so they created a mechanism to do good to ensure the business was safe and their control of it remained by shifting ownership to the charity.

- We know philanthropy and business giving are forces for good, but we tend to see them as coming after success rather than an ongoing feature of business operations. The sisters' story shows that the two can go hand in hand without compromising control or competitiveness.

\section{Reference}

MacKenzie, N. G., Gordon, J., \& Gannon, M. J. (2019). A spirit of generosity: Philanthropy in the Scotch whisky industry. Business History Review, 93(3), 529-552. 